\title{
Immunohistochemical localization of eight phospholipase C isozymes in pancreatic islets of the mouse
}

\author{
Sung Sook Kim ${ }^{1,3}$, Kisun Jun ${ }^{1,4}$, \\ Myungjin Jeong ${ }^{1}$, Sung-Ho Ryu' ${ }^{2}$, \\ Pann-Ghill Suh² and Hee-Sup Shin ${ }^{1,2,5}$ \\ ${ }^{1}$ National Creative Research Initiative Center for Calcium and \\ Learning \\ ${ }^{2}$ Dept. of Life Science, Pohang University of Science and \\ Technology, Pohang \\ ${ }^{3}$ Dept. of Pathology, Ulsan University Hospital, Ulsan, Korea \\ ${ }^{4} \mathrm{CHA}$ General Hospital, Seoul, Korea \\ ${ }^{5}$ Corresponding author: Tel, +82-2-958-6931; \\ Fax, +82-2-958-6937; E-mail: shin@kist.re.kr
}

Accepted 19 September, 2001

Abbreviations: PLC, phospholipase C; PBS, phosphate-buffered saline; DAB, 3,3-diaminobenzidine

\begin{abstract}
The possible involvement of phospholipase C (PLC) in the regulation of insulin secretion is not clearly understood and neither its isozymes expressed nor cellular localization in the pancreatic islets is known. By using specific monoclonal antibodies, we have investigated the expression and localization of eight different PLC isozymes, $\beta 1, \beta 2, \beta 3, \beta 4, \gamma 1, \gamma 2, \delta 1$, and $\delta 2$, in the pancreatic islets of adult mice. Immunohistochemical analysis carried out on paraffin embedded sections showed a distinct pattern of expression for each of the PLC isozymes. In the central part of the islets containing $\beta$ cells, a high level of $\beta 4$ and moderate levels of $\beta 3$ and $\gamma 1$ were expressed, whereas PLC- $\beta 1$ and $-\gamma 1$ were abundantly expressed in the exocrine pancreas. These results demonstrated the heterogeneity in expression of the phospholipase $\mathbf{C}$ isozymes in pancreatic islets. It is conceivable that these isozymes are coupled to different receptors and perform selective tasks in the regulation of insulin secretion for glucose homeostasis.
\end{abstract}

Keywords: pancreatic islet, $\beta$ cell, insulin, isozymes, phospholipase C

\section{Introduction}

Glucose is the major stimulant for insulin secretion; however, the exact mechanism by which glucose ind- uces insulin secretion still remains to be defined (Vadakekalam et al., 1997). Glucose can augment insulin secretion independently of $\mathrm{K}^{+}$channel closure, provided that the cytoplasmic free $\mathrm{Ca}^{2+}$ concentration is elevated (Gembal et al., 1992). A role for phospholipase C (PLC) in this phenomenon has been both claimed (Turk et al., 1993; Zawalich and Zawalich, 1997) and refuted (Gembal et al., 1993; Vadakekalam et al., 1997). Kelly et al. (1994) suggested that the enhanced phosphoinositide $(\mathrm{PI})$ response was partially $\mathrm{Ca}^{2+}$-dependent and might involve activation of distinct isozymes of PLC expressed in the islets. Nevertheless, scarce attention has been paid to determining whether PLC isozymes display a selective localization in different parts of the pancreatic islets. Information on the cellular localization of PLC proteins in an organ showing a remarkable cellular heterogeneity is essential for a better understanding of the specific functions of each isotype. However, current information about the cellular localization of PLC isozymes has so far been mainly limited to the brain and related organs (Ross et al., 1989; Peng et al., 1997). Therefore the pancreatic islet appears to be an interesting region in which to study the distribution of PLC isozymes mainly to provide clues to solving the controversy concerning the role of PLC isozymes in insulin secretion (Gembal et al., 1993; Vadakekalam et al., 1997). Moreover, several protein kinase C (PKC) isozymes, the downstream molecules for the PLC signaling pathway, were found from mouse pancreatic islets (Knutson and Hoenig, 1997). In addition, several reports suggested an active role of $G$ proteins in the insulin regulation (Sharp, 1996). There is some scattered evidence available to suggest that pancreatic islets express certain PLCs (Kelly et al., 1995; Zawalich et al., 1995; Jonas and Henquin, 1996). However, detailed investigation is necessary to understand their precise localizations.

In the present studies we have investigated the expression and localization of eight different PLC isozymes, $\beta 1, \beta 2, \beta 3, \beta 4, \gamma 1, \gamma 2, \delta 1$, and $\delta 2$, in the pancreatic islets of adult mice using specific monoclonal antibodies. It was found that pancreatic islets expressed PLC- $\gamma 1,-\beta 3$, and $-\beta 4$, by immunohistochemistry. To our knowledge, this is the first report to examine the complete set of PLC isozymes in pancreatic islets by immunohistochemistry.

\section{Materials and Methods}

Tissue preparation

Pancreas tissues were obtained from 8 week-old mice 
of the wild type C57BI/6J strain or mutant mice (for PLC$\beta 1$ or $-\beta 4$ ) which were anesthetized and perfused transcardially with $4 \%$ paraformaldehyde in phosphate-buffered saline (PBS). The tissues were immediately fixed with $10 \%$ neutral buffered formalin, dehydrated in ethanol, and embedded in paraffin wax. For immunoblotting, pancreatic islets were obtained by picking from fresh pancreatic tissues on an inverted microscope. The PLC$\beta 1$ and the PLC- $\beta 4$ knock out mice have been described previously (Kim et al., 1997). For hormone studies, both wild type and knock out mice were sacrificed after 16-h fasting.

\section{Immunohistochemistry}

Serial $5-\mu \mathrm{m}$ sections were cut from paraffin embedded tissues. After deparaffinization and hydration, sections were incubated for 20 min with $10 \%$ normal goat serum to block nonspecific serum protein bindings. Immunohistological staining was done as described previously using monoclonal antibodies diluted 1:200 (Suh et al., 1988; Lee et al., 1993; Noh et al., 1994). After incubation for $2 \mathrm{~h}$, sections were washed three times in phosphate-buffered saline and incubated with streptavidinbiotin reagents from the Dako LSAB (labeled streptavidin biotin) Stain kit (Carpenteria, USA). Dako CSA (catalyzed signal amplification) kit was also used to amplify the intensity of staining for PLC- $\beta 1,-\beta 2,-\beta 3$ and $-\delta 2$. In cases of negative control of PLC- $\gamma 1,-\gamma 2$ and $-\delta 1$, parallel sections were incubated with either PLC- $\gamma 1, \gamma 2$ and $\delta 1$ antibodies absorbed with corresponding peptides or PBS, substituting primary antibodies (PLC- $\beta 2,-\beta 3$, and $-\delta 2$ ). PLC- $\beta 1$ and $\beta 4$ knock-out mice were used as negative controls for the PLC- $\beta 1$ and $\beta 4$ staining. As positive controls, the immunohistochemical procedures were repeated using the most representative sections of the various tissues known for expression of each of the isozymes (Homma et al., 1993; Watanabe et al., 1998) (PLC- $\beta 1$ : pyramidal cells of cerebrum, PLC- $\beta 2$ : oligodendrocytes of brain, PLC- $\beta 3$ : myocardial cells of the heart, PLC- $\beta 4$ : Purkinje cells of cerebellum, PLC- $\gamma 1$ : welldifferentiated colon cancer tissue, and PLC- $\gamma 2$ : human B cell lymphoma tissue, PLC- $\delta 1$ : brain tissue). We did not perform staining on positive control tissue for $-\delta 2$. For staining of several hormones, basically the similar method was used. All sections were reacted with 3,3-diaminobenzidine (DAB, Dako), DAB with Nickel (Vector, Burlingame, USA), or 3-amino, 3-ethyl carbazole (Dako) as the chromogen and photographed under the Olympus $\mathrm{BH} 2$ light microscope.

\section{Results}

As shown in Figure 1, mouse pancreatic islets express certain PLC isozymes, but not all eight isozymes (Figure $1 \mathrm{~A}-\mathrm{H})$. The specificity of the immunoreaction was veri- fied by using knock-out mice or by repeating the experiments with antibodies that had been pretreated with the corresponding peptide in the cases of PLC- $\beta 1,-\beta 4,-\gamma 1$, $-\gamma 2$ and $-\delta 1$ (no peptide was available for monoclonal antibodies to PLC- $\beta 2,-\beta 3$, and $-\delta 2)$. After the pretreatment or in knock-out mice, any immunoreactivity was completely abolished in each case. Moreover we applied several negative and positive controls, as described in Materials and Methods, and results on the observed localization of the various PLC isozymes were in good agreement with the results available in the literature (Suh et al., 1988; Ross et al., 1989; Homma et al., 1993; Lee et al., 1993; Noh et al., 1994; Peng et al., 1997; Watanabe et al., 1998).

The PLC- $\beta 1$ immunoreactivity was observed in the exocrine pancreas but not in the islets of the wild type mice, whereas this was not observed in the PLC- $\beta 1$ knock-out mice. We tried to amplify the signal using the Dako CSA kit, but this isozyme was still not detectable in pancreatic islet. PLC- $\beta 2$ showed a negative result in the islets even with the amplification staining method, although the same antibody detected this enzyme in oligodendrocytes of the brain. PLC- $\beta 3$ was negative in the islet by the routine staining method, whereas it was positive in the cardiac muscle cells. But when using the amplification staining method, this enzyme showed strong immunoreactivity in the pancreatic islet. Diffuse and intense expression of PLC- $\beta 4$ was detected in the cytoplasm of islet cells even without the signal amplification. We used PLC- $\beta 4$ knock-out mice as a negative control, and the definite and intense expression of PLC$\beta 4$ obtained in wild type mice was abolished in the pancreatic islet of the knock-out mice (Figure 2A, B). The PLC- $\beta 4$ positive cells were located in the central part of the pancreatic islet, and were confirmed to be beta cells since they were also positive for insulin and negative for glucagon, somatostatin (Figure 3A-D), and pancreatic polypeptide (data not shown). PLC- $\gamma 1$ was positive in both exocrine and endocrine pancreas. These positive reactions were abolished with the prior incubation of anti PLC- $\gamma 1$ antisera with PLC- $\gamma 1$ peptide (Figure 2C, D), indicating that the diffuse PLC- $\gamma 1$ staining in the pancreas was specific. The PLC- $\gamma 2,-\delta 1$, and $-\delta 2$ were not expressed in the pancreas even with the amplification method, although these enzymes were positively stained in B-lymphocytes $(\gamma 2)$ or neurons of the brain $(\delta 1)$. In summary, we detected strong staining for PLC - $\beta 4$, and moderate staining for PLC $-\beta 3$ and $-\gamma 1$ in the pancreatic islet, whereas $\beta 1$ and $\gamma 1$ predominated in the exocrine part.

\section{Discussion}

Even though the presence of several PLC isozymes was confirmed in pancreatic islets (Jonas and Henquin, 

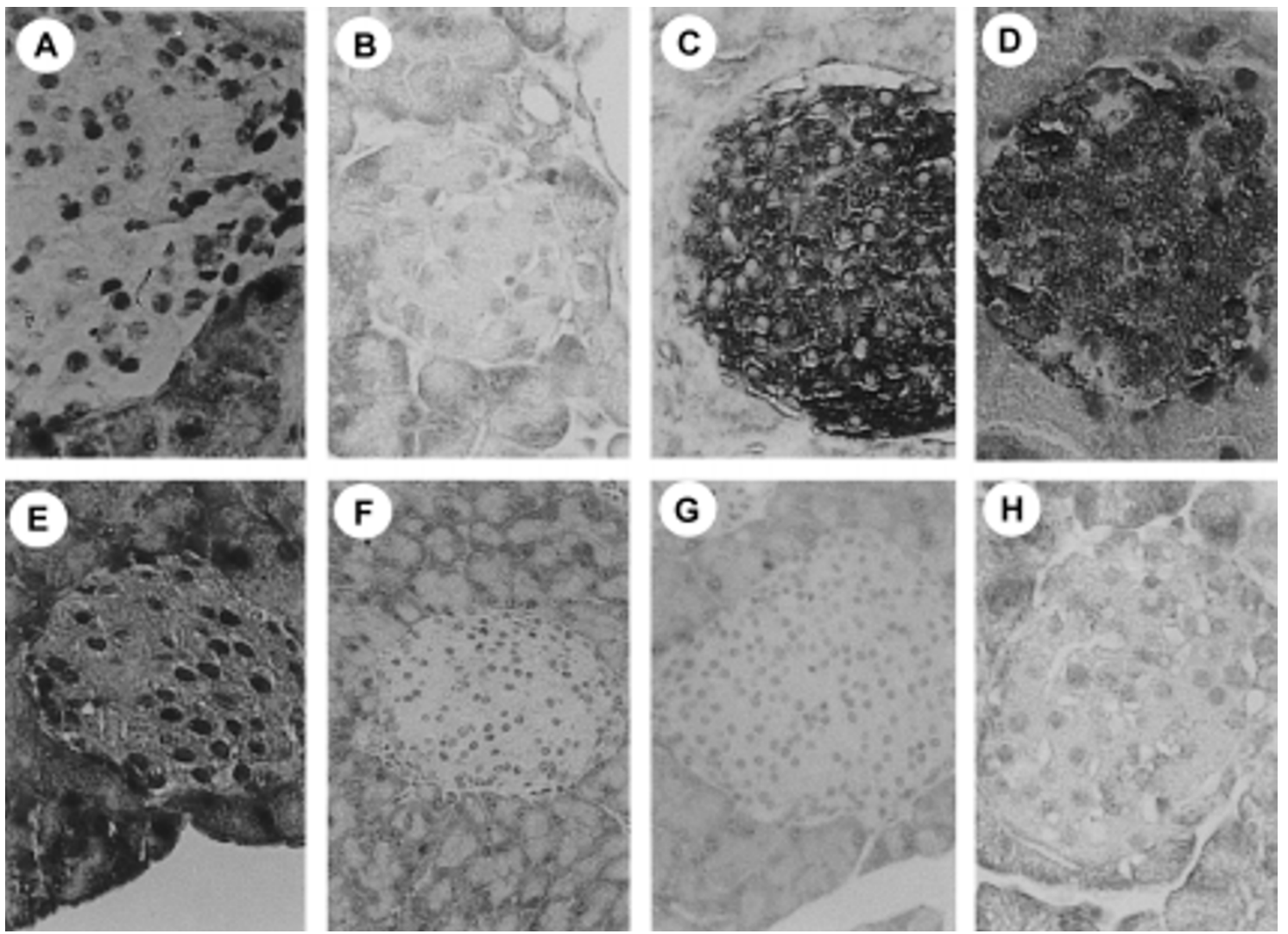

Figure 1. Immunohistochemistry of PLC isozymes in pancreatic islet: PLC- $\beta 3, \beta 4, \gamma 1$ were expressed in islet, $\beta 1$ and $\gamma 1$ were in exocrine pancreas. A. PLC-

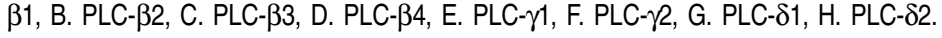
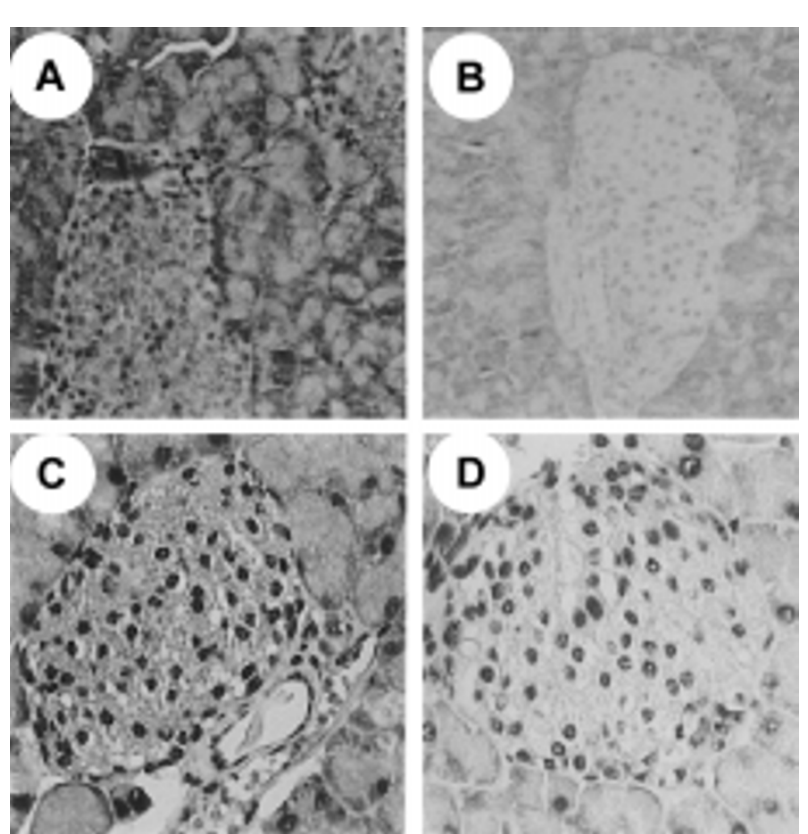

Figure 2. PLC- $\beta 4$ and $\gamma 1$ expression in pancreatic islet with negative controls: the expressions of PLC- $\beta 4$ and $\gamma 1$ were abolished in negative controls. A. PLC- $\beta 4$ in wild type mice (+/+), B. PLC- $\beta 4$ in knock-out mice $(-/-)$, C. PLC- $\gamma 1$ with monoclonal antibody, D. PLC- $\gamma 1$ with preadsorption.
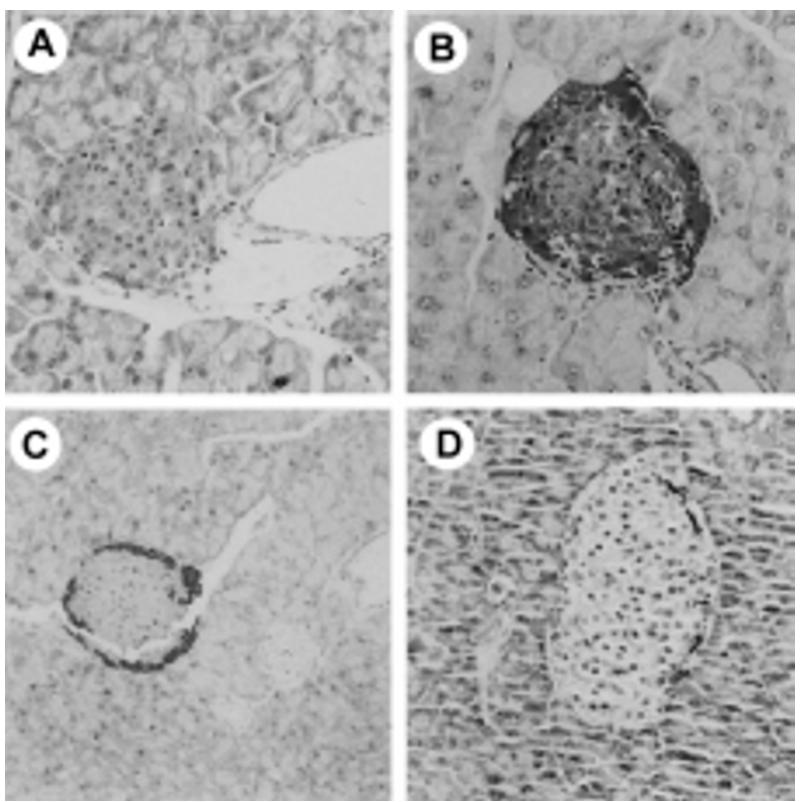

Figure 3. PLC- $\beta 4$ expression in beta cells of pancreatic islet; the beta cells expressed PLC- $\beta 4$. A. PLC- $\beta 4$ immunostain in beta cells of pancreatic islet, B. Insulin immunostain in beta cells of pancreatic islet, C. Glucagon immunostain in alpha cells of pancreatic islet, D. Somatostatin immunostain in delta cells of pancreatic islet. 
1996; Zawalich et al., 1995; Kelly et al., 1995), systematic classification has been difficult due to limited knowledge on their distribution. Zawalich and Zawalich (1997) demonstrated an augmentation of $\mathrm{Ca}^{2+}$-induced inositol phosphate generation in rat islets when diazoxide is present. They further suggested that activation of the PLC-PKC pathway plays an important role in the fuel-induced insulin secretion. The present study aimed at the comprehensive examination on the localization of eight isozymes of PLC in pancreatic tissues.

PLC- $\beta 1$ is known to mediate pertussis toxin-insensitive phosphoinositide hydrolysis (Rhee and Choi, 1992). Coupling of the enzyme to a cell-surface receptor is mediated by GTP-binding protein Gq (Rhee and Choi, 1992). In this study, PLC- $\beta 1$ expression was not found in pancreatic islets and only at a low level in exocrine pancreas, as reported previously (Piiper et al., 1997). No evidence of the PLC- $\beta 2$ was found in both exocrine and endocrine pancreas even with the CSA amplification method. These findings suggest that PLC- $\beta 1$ and $-\beta 2$ do not participate in the insulin regulation signaling.

We found a moderate expression of PLC- $\beta 3$ in pancreatic islets using the amplification method, whereas no expression was found with the routine $A B C$ method, using the LSAB kit, indicating that pancreatic islets express PLC- $\beta 3$ at a relatively lower level than any other organs such as the heart. Considering that PLC$\beta 3$ is present ubiquitously and PLC- $\beta 3$ knock-out mice died at early embryo (Wang et al., 1998), PLC- $\beta 3$ may play some role in insulin secretion. Further investigation, however, is necessary to define its precise functional role during the insulin secretion process.

Recent reports implicated that PLC- $\beta 4$ was activated by the a subunit of the $\mathrm{Gq}$ family of $\mathrm{G}$ proteins to mediate phosphoinositide hydrolysis (Ross et al., 1989; Peng et al., 1997). There are both selectivity and promiscuity in the G protein action inside the $\beta$ cells (Sharp, 1996). Specifically, $\mathrm{Gq}$ and $\mathrm{G} \alpha 11$ protein, which are known to activate PLC- $\beta 4$, are located in the islets (Verspohl and Herrmann, 1996; Shah BH, 1999). Our results suggest a possibility that PLC- $\beta 4$ is an important constituent in the signaling pathway inside the $\beta$ cells of the pancreatic islet.

PLC- $\gamma 1$ was also expressed in the central part of the islets as well as in the exocrine pancreas. PLC- $\gamma 1$ is known to be involved in the secretory function of the acinar cells (Wrenn et al., 1996). Its location of expression suggests the PLC- $\gamma 1$ 's role in mediating transduction events underlying trophic signals inside the insulinsecreting $\beta$ cells. This idea is consistent with the observation that the $\gamma 1$ isotype is involved in cellular response to growth factors.

PLC- $\gamma 2,-\delta 1$ and $-\delta 2$ were not found in the pancreatic islet. Gasa et al. (1999) recently reported that PLC- $\beta 1$, $-\beta 2,-\beta 3,-\gamma 1$, and $-\delta 1$ were expressed in insulinoma cell line and rat islets. Also, the report by Kim et al. (2001) demonstrated that all four PLC- $\beta$ isozymes and two PLC- $\delta$ were detected in the islets, but PLC- $\gamma 1$ and $-\gamma 2$ were not observed in rat pancreatic islets. The possible explanations for the discrepancy between the results of ours and that of others include the differences of species (mouse vs rat), specimens (tissue vs cell), methods (immunohistochemistry vs immunoblotting), and antibodies used.

In conclusion, we believe that our data add valuable insight into understanding the possible function of PLC isozymes in the regulation of insulin secretion. However, it still remains to be elucidated that these molecules in fact play inhibitory or stimulatory functions in insulin secretion.

\section{References}

Gasa R, Trinh KY, Yu K, Wilkie TM, Newgard CB. Overexpression of Go11 and isoforms of PLC in islet $\beta$-cells reveals a lack of correlation between inositol phosphate accumulation and insulin secretion. Diabetes 1999;48:103544

Gembal M, Gilton P, Henquin JC. Evidence that glucose can control insulin release independently from its action on ATPsensitive $\mathrm{K}^{+}$channels in mouse $\beta$ cells. J Clin Invest 1992; 89:1288-95

Gembal M, Detimary P, Gilton P, Gao ZY, Henquin JC. Mechanism by which glucose can control insulin release independently from its action on adenosine trisphosphatesensitive $\mathrm{K}^{+}$channels in mouse $\beta$-cells. J Clin Invest 1993; 91:871-80

Homma Y, Emori Y, Shisabaki F, Suzuki K, Takenawa T. Isolation and characterization of a $\gamma$ type phosphoinositidespecific phospholipase C (PLC- $\gamma 2)$. Biochem J 1993;269:1318

Jonas JC, Henquin JC. Possible involvement of a tyrosine kinase-dependent pathway in the regulation of phosphoinositide metabolism by vanadate in normal mouse islets. Biochem J 1996;315:49-55

Kelley GG, Zawalich WS, Zawalich KC. Calcium and a mitochondrial signal interact to stimulate phosphoinositide hydrolysis and insulin secretion in rat islets. Endocrinol 1994;134:1648-54

Kelley GG, Zawalich KC, Zawalich WS. Synergistic interaction of glucose and neurohumoral agonists to stimulate islet phosphoinositide hydrolysis. Am J Physiol 1995;269:E575-82

Kim D, Jun KS, Lee SB, Kang NG, Min DS, Kim YH, Ryu SH, Suh PG, Shin HS. Phospholipase C isozymes selectively couple to specific neurotransmitter receptors. Nature 1997; 389:290-93

Kim MJ, Lee KH, Min DS, Yoon SH, Hahn SJ, Kim MS, Jo $\mathrm{YH}$. Distributional patterns of phospholipase $\mathrm{C}$ isozymes in rat 
pancreas. Pancreas 2001;22:47-52

Knutson KL, Hoenig M. Subnuclear localization of protein kinase C delta in beta cells. Biochem Mol Med 1997;62:50-57

Lee CW, Park DJ, Lee KH, Kim CH, Rhee SG. Purification, molecular cloning, and sequencing of phospholipase C- $\beta 4$. J Biol Chem 1993;268;21318-27

Noh DY, Lee Y.H., Kim SS, Kim YI, Ryu SH, Suh PG, Park JG. Elevated content of phospholipase $\mathrm{C}-\gamma 1$ in colorectal tissues. Cancer 1994;73:36-41

Peng YW, Rhee SG, Yu WP, Ho YK, Schoen T, Chader GJ, Yau KW. Identification of components of a phosphoinositide signaling pathway in retinal rod outer segments. Proc Natl Acad Sci USA 1997;94:1995-2000

Piiper A, Stryjek-Kaminska D, Klengel R, Zeuzem S. Epidermal growth factor inhibits bombesin-induced activation of phospholipase C- $\beta 1$ in rat pancreatic acinar cells. Gastroenterol 197;113:1747-55

Rhee SG, Choi KD. Regulation of inositol phospholipidspecific phospholipase C isozymes. J Biol Chem 1992;267: 12393-96

Ross CA, MacCumber MW, Glatt CE, Snyder SH. Brain phospholipase $\mathrm{C}$ isozymes: differential mRNA localizations by in situ hybridization. Proc Natl Acad Sci USA 1989;86:2923-27

Shah $\mathrm{BH}$. Cholera toxin mediated regulation of the expression of $\mathrm{Gq} \alpha$ and G11 $\alpha$ GTP binding proteins. Exp Mol Med 1999;31:89-94

Sharp GW. Mechanism of inhibition of insulin release. Am J Physiol 1996;271:C1781-99

Suh PG, Ryu SH, Choi WC, Lee KY, Rhee SG. Monoclonal antibodies to three phospholipase $\mathrm{C}$ isozymes from rat brain.
J Biol Chem 1988; 263:14497-504

Turk J, Gross RW, Ramanadham S. Amplification of insulin secretion by lipid messengers (review). Diabetes 1993;42: 367-74

Vadakekalam J, Rabaglia ME, Metz SA. Roles of GTP and phospholipase $\mathrm{C}$ in the potentiation of $\mathrm{Ca}(2+)$-induced insulin secretion by glucose in rat pancreatic islets. $\mathrm{J}$ Endocrinol 1997;153:61-71

Verspohl EJ, Herrmann K. Involvement of G proteins in the effect of carbachol and cholecystokinin in rat pancreatic islets. Am J Physiol 1996;271:E65-72

Wang S, Geber-Medhin S, Betcholth C, Stalberg P, Zhou Y, Larsson C, Weber G, Feinstein R, Oberg K, Gobl A, Skogseid $B$. Targeted disruption of the mouse phospholipase $C$ - $\beta 3$ gene results in early embryonic lethality. FEBS Lett 1998;441:26165

Watanabe M, Nakamura M, Sato K, Kano M, Simon MI, Inoue Y. Patterns of expression for the mRNA corresponding to the four isozymes of phospholipase $\mathrm{C}-\beta$ in mouse brain. Eur $\mathrm{J}$ Neurosci 1998;10:2016-25

Wrenn RW, Creazzo TL, Herman LE. $\beta 1$ integrin ligation stimulates tyrosine phosphorylation of phospholipase $C \gamma 1$ and elevates intracellular $\mathrm{Ca}^{2+}$ in pancreatic acinar cells. Biochem Biophy Res Commun 1996;226:876-82

Zawalich WS, Zawalich KC, Kelly GG. Regulation of insulin release by phospholipase $C$ activation in mouse islet: differential effects of glucose and neurohumoral stimulation. Endocrinol 1995;136:4903-9

Zawalich WS, Zawalich KC. Regulation of insulin secretion via ATP-sensitive $\mathrm{K}^{+}$channel-independent mechanism: role of phospholipase. Am J Physiol 1997;272:E671-77 